Jurnal Review Pendidikan dan Pengajaran

http://journal.universitaspahlawan.ac.id/index.php/jrpp

Volume 3 Nomor 2, Desember 2020

P-2655-710X e-ISSN 2655-6022
Submitted : $\quad 28 / 10 / 2020$

Reviewed: $10 / 11 / 2020$

Accepted : $20 / 11 / 2020$

Published: $03 / 12 / 2020$
Arozatulo

Bawamenewi ${ }^{1}$

\section{ANALISIS TINDAK TUTUR BAHASA NIAS SEBUAH KAJIAN PRAGMATIK}

\begin{abstract}
Abstrak
Penggunaan bahasa dalam berkomunikasi memerlukan dua sarana penting, yakni sarana linguistik dan sarana pragmatik. Sarana linguistik berkaitan dengan ketepatan bentuk dan struktur bahasa, sedangkan sarana pragmatik berkaitan dengan kecocokan bentuk dan struktur dengan konteks penggunaannya. Kendala pada sarana linguistik lebih sering dihadapi oleh pembelajar bahasa Indonesia pemula, sedangkan sarana pragmatik lebih sering menjadi kendala bagi pembelajar tingkat menengah dan tingkat lanjut. Melihat kenyataan seperti itu, kaum semantik generatif berusaha keras untuk bisa menemukan batasan yang jelas antara semantik dan pragmatik dalam arti yang luas. Secara umum metode penelitian diartikan sebagai cara ilmiah untuk mendapatkan data dengan tujuan dan kegunaan tertentu. Langkah-langkah dalam penelitian ini yaitu: (1). Untuk data yang diperoleh sebagai temu bual, dilakukan implikasi daripada bahan serta klarifikasi kumpulan sesuai dengan materi kajian,dan (2). Data kualitatif daripada sumber primer maupun sekunder diberikan penafsiran secara kualitatif. Penggunaan angka hanya sebatas angka persentase.
\end{abstract}

Kata Kunci: Tindak, Tutur, Pragmatik

\begin{abstract}
The use of language in communication requires two necessary means, namely linguistic means, and pragmatic means. Linguistic means relate to the accuracy of the form and structure of the language. In contrast, pragmatics means are associated with the suitability of shapes and structure with the context of their use. Constraints on linguistic means are often faced by budding Indonesian learners, while pragmatic means are often an obstacle for intermediate and advanced learners. Looking at such a reality, generative semantics go to great lengths to find a clear boundary between semantics and pragmatics in a broad sense. In general, research methods are defined as scientific ways to obtain data with specific purposes and uses. This study's steps are: (1) for data obtained as an interview, the implications of the material and clarification of the group by the study materials, and (2). Qualitative data from primary and secondary sources are given qualitative interpretation. The use of numbers is only a percentage number.
\end{abstract}

Keywords: Action, Speech, Pragmatic

\footnotetext{
${ }^{1}$ Program Studi Pendidikan Bahasa Indonesia, Dosen Tetap IKIP Gunungsitoli (Yaperti Nias) Email : arozatulobawamenewi825@gmail.com
} 


\section{PENDAHULUAN}

Pragmatik adalah kajian tentang penggunaan bahasa sesungguhnya. Pragmatik mencakup bahasan tentang deiksis, praanggapan, tindak tutur, dan implikatur percakapan. Dalam kehidupan di masyarakat manusia selalu melakukan interaksi atau hubungan dengan sesamanya adalah bahasa. Bahasa dan manusia merupakan dua hal yang tidak dapat dipisahkan, dalam arti keduanya berhubungan erat. Bahasa merupakan alat komunikasi yang paling penting bagi manusia karena dengan bahasa manusia dapat mengekspresikan apa yang ada dalam pikiran atau gagasannya (Zagoto, 2020; Sarumaha, 2018). Bahasa Nias pada hakikatnya merupakan alat komunikasi untuk menyampaikan sesuatu secara verbal kepada lawan bicara. Bahasa Nias hingga sekarang masih dalam tanda kutip asal-usulnya, banyak para arkeologi menjelaskan bahwa bahasa ini merupakan salah satu bahasa di dunia yang masih belum diketahui persis dari mana asalnya. Cara bertutur orang Nias pada umumnya cukup unik. Vokal suara keras dan lepas dengan bunyi-bunyi bahasa yang sulit disimak oleh orang luar. Iramanya cepat. Dan tidak memiliki konsonan akhir dalam bahasa tutur sehari-hari. Bahasa Nias ini dapat dikategorikan sebagai bahasa yang unik karena merupakan satu-satunya bahasa di dunia yang setiap akhiran katanya berakhiran huruf vokal. Bahasa Nias mengenal enam huruf vokal, yaitu A, E, I, U, O dan ditambah dengan Ö. Seseorang akan melakukan tindakan meminta dengan berbagai cara tergantung dari situasi dan kondisi penutur. Jika penutur dalam situsi emosi marah akan berujar semaunya dan tidak perduli orang yang dihadapannya berkata apa. Sebaliknya jika penutur berada dalam situasi santai akan berujar dengan sopan dan menyenangkan sehingga orang yang diajak berbicara senang. Fungsi bahasa secara praktis adalah sebagai alat komunikasi yang digunakan untuk bekerjasama, berinteraksi, dan mengidentifikasikan diri. Fungsi bahasa dalam hal ini tidak dapat dipisahkan dari konteks situasi dan konteks budaya yang melatarbelakangi bahasa itu. Bahasa juga digunakan untuk mengungkapkan banyak hal menyangkut penutur dan petutur, seperti informatif-naratif refresentasional, diri sendiri, memengaruhi orang lain, dan imajinatif atau estetis. Fungsi bahasa dalam arti pemakaian atau penggunaan bahasa oleh penuturnya merupakan suatu peristiwa sosial (Ferdiansyah, 2020; Bawamenewi, 2019; Masril, 2020).

Pulau Nias yang semasa prabencana hampir tidak pernah muncul di 'radar' pembangunan, terkenal karena pemandangan alamnya yang masih asli, pantai berselancarnya yang terpencil, dan lingkungannya yang bernuansa pedesaan. Pulau Nias selayaknya serumpun dalam berbahasa yang tidak memiliki konsonan pada setiap akhir kata melalui tuturan, namun di sisi lain Kota Telukdalam Kabupaten Nias khususnya memiliki keunikan tersendiri dalam berkomunikasi yang jauh berbeda dari empat kabupaten dan kota Gunungsitoli di Pulau Nias. Salah satu contohnya 'Haega gömöi', 'mau kemana' namun hal ini tidak terlepas dari hukum bahasa Nias. Dengan keadaan seperti tindak tutur berkomunikasi menjadi problema dalam kajian pragmatik. Sebagai alat komunikasi yang paling vital, bahasa, ketika digunakan, dapat dijadikan media yang efektif bagi para partisipan untuk saling memperkenalkan dan menafsirkan keunikan budayanya masing-masing (Azman, 2020; Fajra, 2020).

Studi perbedaan-perbedaan harapan berdasarkan skemata budaya merupakan bagian dari ruang lingkup yang luas yang umumnya dikenal sebagai pragmatik lintas budaya. Untuk melihat bagaimana cara penutur menyusun makna berdasar budaya yang berbeda sesungguhnya memerlukan penilaian kembali secara lengkap dari segala sesuatu yang sebenarnya sudah kita pertimbangkan sampai disini dalam survey ini. Konsep-konsep terminologi itu mungkin memberikan suatu kerangka anilitik dasar, tetapi realisasi dari konsep-konsep itu mungkin berbeda secara substansial dengan contoh bahasa inggris yang diberikan di sini. Dengan keadaan tersebut pesatnya era globalisasi adat dan budaya Nias pun punah drastis tanpa peduli lagi. Padahal, pada hakikatnya budaya Nias khususnya bahasa daerah Nias sangat unik dengan yang lain. Namun, sangat disayangkan zaman sekarang semakin terpuruk dengan masuknya budaya Barat seakan dikelabui keegoisan seseorang. Karena letak geografisnya yang terletak diantara budaya dan bahasa yang berbeda. Sehingga dalam pemakaian bahasa kehidupan sehariharinya sering menggunakan bahasa bercampur aduk tidak bisa dihindari walaupun merupakan dari pengaplikasian salahsatu fungsi bahasa sendiri yaitu bahasa sebagai alat komunikasi. Oleh 
karena itu penulis akan meneliti tindak tutur sebagai kajain pragmatik yang tercipta dari orangorang Nias.

Tindak tutur (speech action) merupakan unsur pragmatik yang melibatkan pembicara, pendengar atau penulis, pembaca serta yang dibicarakan. Dalam penerapannya tindak tutur digunakan oleh beberapa disiplin ilmu. Seorang kritikus sastra mempertimbangkan teori tindak tutur untuk menjelaskan teks yang halus (sulit) atau untuk memahami alam gnre (jenis) sastra, para antropolog akan berkepentingan dengan teori tindak tutur ini dapat mempertimbangkan mantra magis dan ritual, para filosof melihat juga adanya aplikasi potensial diantara berbagai hal, status pernyataan etis, sedangkan linguis (ahli bahasa) melihat gagasan teori tindak tutur sebagai teori yang dapat diterapkan pada berbagai masalah di dalam kalimat (sintaksis), semantic, pemelajar bahasa kedua, dan yang lainnya. Di dalam linguistic pragmatic tindak tutur tetap merupakan praduga dengan implikatur khusus. (Setiawan, 2005; Zagoto, 2019).

Tindak tutur atau " pertuturan " / " speech act , speech event " (istilah krida laksana) adalah pengujaran kalimat untuk menyatakan agar suatu maksud dari pembicara dapat diketahui oleh pendengar (Kridalaksana, 1984: 154). Semua interaksi lingual terdapat tindak tutur (Searle dalam Aslinda 2010: 33). Interaksi lingual bukan hanya lambang, kata atau kaliamat, melainkan lebih tepat bila disebut produk atau hasil dari lambang, kata, atau kalimat yang berwujud perilaku tindak tutur. Menurut Aslinda (2010: 34), Ada empat faktor yang menentukan tindak tutur diantaranya, adalah sebagai berikut:

a. Dengan bahasa apa dia harus bertutur,

b. Kepada siapa dia harus menyampaikan tuturan,

c. Dalam situasi bagaimana tuturan itu disampaikan, dan

d. Kemungkinan-kemungkinan struktur manakah yang ada dalam bahasa yang digunakan.

Dikatakan, Tindak tutur adalah produk atau hasil dari suatu kalimat dalam kondisi tertentu dan merupakan kesatuan terkecil dari interaksi lingual. Secara sederhana dapat dikatakan bahwa tindak tutur yang dikatakan adalah sepenggal tuturan yang dihasilkan sebagai bagian terkecil dalam interaksi lingual. Tindak tutur dapat berupa pernyataan, pertanyaan, dan perintah. Dengan demikian, satu maksud tuturan perlu dipertimbangkan berbagai kemungkinan tindak tutur sesuai dengan posisi penutur, situasi tutur, dan kemungkinan struktur yang ada dalam bahasa itu.

Menurut Chaer (2010: 61-72) Variasi atau ragam bahasa merupakan bahasan pokok dalam studi sosiolinguistik, sehingga Kridalaksana (1974) mendefinisikan sosiolinguistik sebagai cabang linguistik yang berusaha menjelaskan ciri-ciri variasi bahasa dan menetapkan korelasi ciri-ciri variasi bahasa tersebut dengan ciri-ciri variasi bahasa tersebut dengan ciri-ciri sosial kemasyarakatan.

a. Variasi bahasa

b. Variasi dari Segi Penutur

c. Variasi dari Segi Pemakaian

d. Variasi dari Segi Keformalan

e. Variasi dan Segi Sarana

Tindak tutur merupakan gejala individual yang bersifat psikologis, dan keberlangsungannya ditentukan oleh kemampuan bahasa si penutur dalam meghadapi situasi tertentu. Dalam peristiwa tutur lebih dilihat tujuan peristiwanya, tetapi dalam tindak tutur lebihmemperhatikan makna atau arti tindakan dalam tuturannya. Tindak Tutur lokusi adalah tindak tutur yang menyatakan sesuatu dalam arti "berkata" atau tindak tutur dalam bentuk kalimat yang bermakna dan dapat dipahami. Tindak tutur ilokusi adalah tindak tutur yang biasanya diidentifikasikan dengan kalimat performatif yang eksplisit. Tindak ilokusi ini biasanya berkenaan dengan pemberian izin, mengucapkan terima kasih, menyuruh menawarkan, dan menjanjikan. Tindak tutur perlokusi adalah tindak tutur yang berkenaan dengan adanya ucapan orang lain sehubungan dengan sikap dan perilaku non linguistik dari orang lain itu.

Makna lokusi adalah makna harfiah atau makna secara stuktur tanpa diembeli pemahaman subjektif dari sudut penutur atau pendengar. Makna ilokusi adalah makna yang dipahami pendengar dari tuturan yang diujarkan penutur. Makna perlokusi adalah makna yang 
dimaksud penutur kepada pendengar. Contoh ketiga makna tersebut ada dalam percakapan berikut yang diambil dari Chaer (2009: 78).

Seorang laki-laki tua bertanya kepada pelayan toko peti mati.

"Berapa harga peti mati penuh ukiran ini?"

"Dua juta, tuan." Jawab si pelayan toko.

"Wah, mahal amat." Sahut laki-laki tua itu dengan kaget.

"Tapi, tuan." Kata pelayan toko itu menjelaskan, "Kami jamin kalau tuan sudah masuk ke dalamnya, tuan pasti tidak ingin keluar lagi!"

a. Ilokusi

Ada beberapa jenis tindakan tutur yaitu:

Tindak tutur ilokusi adalah tindak tutur yang biasanya diidentifikasikan dengan kalimat performatif yang eksplisit. Tindak ilokusi ini biasanya berkenaan dengan pemberian izin, mengucapkan terima kasih, menyuruh menawarkan, dan menjanjikan. Misalnya, ibu guru menyuruh saya agar segera berangkat". Kalau tindak tutur ilokusi hanya berkaitan dengan makna, maka makan tindak tutur ilkusi berkaitan dengan nilai, yang dibawakan preposisinya. Yang dimaksud dengan makna ilokusi adalah makna seperti yang dipahami oleh pendengar. Tindak tutur ilokusi adalah tindak melakukan sesuatu. Di sini kita mulai berbicara tentang maksud dan fungsi atau daya ujaran yang bersangkutan, untuk apa ujaran itu dilakukan. Jadi, "Aku ngelak" yang diujarkan oleh P dengan maksud 'minta minum' adalah sebuah tindak ilokusi.

Tindak ilokusi ini merupakan bagian yang penting dalam memahami tindak tutur (Wijana 1996:19). Tindak ilokusi disebut sebagai The Act of Doing Something. Leech (dalam Rustono 1999:38) menjelaskan bahwa untuk mempermudah identifikasi ada beberapa verba yang menandai tindak tutur ilokusi, antara lain melaporkan, mengumumkan, bertanya, menyarankan, berterimakasih, mengusulkan, mengakui, mengucapkan selamat, berjanji, mendesak, dan sebagainya. Contoh :

(1) "Nasi pecel pak ali itu enak"

(2) "Jalan disana licin "

(3) "dirumah itu banyak setanya “

b. Lokusi

Wijana (Dalam Setiawan, 2005:18-19) menyatakan bahwa tindak lokusi adalah tindak tutur untuk meyatakan sesuatu. Tindak tutur ini disebut The Act of Saying Something. Konsep lokusi adalah konsep yang berkaitan dengan proposisi kalimat. Kalimat atau tuturan dalam hal ini dipandang sebagai suatu satuan yang terdiri atas dua unsur, yakni subjek atau topik dan predikat atau comment yang relative paling mudah untuk diidentfikasikan karena pengidentifikasiannya cenderung dapat dilakukan tanpa menyertakan konteks tertuturnya tercakup dalam situasi tutur. Contoh :

(1) "Saya sedang makan"

(2) "ibu ke pasar"

(3) "tas itu bagus"

c. Perlokusi

Menurut Wijana (dalam Setiawan, 2005:25) tindak perlokusi adalah tindak tutur yang pengaturannya dimaksud untuk mempengaruhi lawan tutur. Subyakto-Nababan (dalam Setiawan, 2005:25) memberian definisi mengenai tindak perlokusi, yaitu tindak bahasa yang dilkakukan sebagai akibat atau efek dari suatu ucapan orang lain. Rustono (1999:38) menyatakan bahwa tindak tutur perlokusi adalah tindak tutur yang pengujarannya dimaksudkan untuk mempengaruhi mitra tutur. Sementara itu Tarigan (1987:35) mengatakan bahwa ujaran yang diucapkan penutur bukan hanya peristiwa ujar yang terjadi dengan sendirinya, tetapi merupakan ujaran yang diujarkan mengandung maksud dan tujuan tertentu yang dirancang untuk menghasilkan efek, pengaruh atau akibat terhadap lingkungan mitra tutur atau penyimak. 
Dengan demikian dapat dikatakan bahwa tindak tutur perlokusi berhubungan dengan sikap dan perilaku nonlinguistik. (Chaer 1995:70) Contoh tindak tutur perlokusi :

(1)." saya tidak punya uang pak!"

(2).“ Kemarin saya terlambat !"

(3).“Ada pencuri !"

Hal ini sejalan dengan pendapat Austin (1962) yang melihat adanya tiga jenis tindak ujar, yaitu tindak lokusi (melakukan tindakan mengatakan sesuatu), tindak ilokusi (melakukan tidakan dalam mengatakan sesuatu), dan tindak perlokusi (melakukan tindakan dengan mengatakan sesuatu).

Tabel 1. Jenis Tindak Tutur

\begin{tabular}{|c|l|}
\hline \multirow{3}{*}{ Lokusi } & $\begin{array}{l}\boldsymbol{n} \text { mengatakan kepada } \boldsymbol{t} \text { bahwa } \boldsymbol{X} \text {. (merupakan tindak mengatakan sesuatu: } \\
\text { menghasilkan serangkaian bunyi yang berarti sesuatu. Ini merupakan aspek bahasa } \\
\text { yang merupakan pokok penekanan linguistik tradisional). }\end{array}$ \\
\hline \multirow{5}{*}{ Ilokusi } & $\begin{array}{l}\text { Dalam mengatakan X, n menegaskan (asserts) bahwa P. (Dilakukan dengan } \\
\text { mengatakan sesuatu, dan mencakup tindak-tindak seperti bertaruh, berjanji, menolak, } \\
\text { dan memesan. Sebagian verba yang digunakan untuk melabel tindak ilokusi bisa } \\
\text { digunakan secara performatif. Dengan demikian mengatakan Saya menolak bahwa } \\
X \text { sama halnya menolak bahwa X.) }\end{array}$ \\
\hline \multirow{5}{*}{$\begin{array}{l}\text { Dengan mengatakan X, n meyakinkan (convinces) t bahwa P. (Menghasilkan efek } \\
\text { tertentu pada pendengar. Persuasi merupakan tindak perlokusi: orang tidak dapat } \\
\text { mempersuai seseorang tentang sesuatu hanya dengan mengatakan Saya mempersuasi } \\
\text { anda. Contoh-contoh yang sesuai adalah meyakinkan, melukai, menakut-nakuti, dan } \\
\text { membuat tertawa ) }\end{array}$} \\
\hline
\end{tabular}

Istilah pragmatik pertama-tama digunakan oleh filosof kenamaan Charles Morris (1938). Filosof ini memang mempunyai perhatian besar terhadap ilmu yang mempelajari system tanda (semiotik). Dalam semiotik ini, dia membedakan tiga konsep dasar yaitu sintaktik, semantik, dan pragmatik. Sintaktik mempelajari hubungan formal antara tanda-tanda. Semantik mempelajari hubungan antara tanda dengan objek. Pragmatik mengkaji hubungan antara tanda dengan penafsir (interpreters). Tanda-tanda yang dimaksud di sini adalah tanda-tanda bahasa bukan yang lain.

Pengajaran bahasa sering dipisahkan dari pengajaran budaya (culture), bahkan ada yang menganggap bahwa bahasa tidak ada hubungannya dengan budaya. Memang diakui bahwa budaya penting untuk dipahami oleh pemelajar bahasa, tetapi pengajarannya sering terpisah dari pengajaran bahasa. Joan Kelly Hall (2002) menyebutkan bahwa ancangan kemampuan komunikatif (communicative competence), misalnya, memang mempertimbangkan aspek budaya dalam pembelajaran bahasa dengan lebih menekankan pada penggunaan bahasa, tetapi dalam pelaksanaannya bahasa masih dianggap sebagai satu sistem homogen yang terpisah dari interaksi penutur dalam kehidupan sehari-hari (Zagoto, 2018).

\section{METODE}

Secara umum metode penelitian diartikan sebagai cara ilmiah untuk mendapatkan data dengan tujuan dan kegunaan tertentu. Nana (2010:99) mengatakan penelitian kualitatif menggunakan desain penelitian studi kasus dalam arti penelitian difokuskan pada satu fenomena saja yang dipilih dan ingin dipahami secara dengan mengabaikan fenomena-fenomena lainnya. Dengan melakukan penelitian dapat digunakan untuk memahami, memecahkan dan mengantisipasi masalah. Sugiyono (2008:284) mengatakan peneliti kualitatif yang merubah masalah atau ganti judul penelitiannya setelah memasuki lapangan penelitian atau setelah selesai merupakan peneliti kualitatif yang lebih baik, karena ia dipandang mampu melepaskan apa yang telah dipikirkan sebelumnya, dan selanjutnya mampu melihat fenomena secara lebih luas dan mendalam sesuai dengan apa yang terjadi dan berkembang pada situasi sosial yang 
diteliti. Lokasi penelitian dilaksanakan di SD Negeri NO. 078467 Buhawa Hilimbowo khususnya dalam kajian bahasa Kabupaten Nias Selatan. Prosedur Pengumpulan Data dengan melakukan Observasi, Wawancara dan Dokumentasi. Maryaeni (2010:75) mengatakan analisis merupakan kegiatan: 1) pengurutan data sesuai dengan rentang permasalahan atau urutan pemahaman yang ingin diperoleh; 2) pengorganisasian data dalam formasi, kategori, ataupun unit perian tertentu sesuai dengan antisipasi peneliti; 3) interpretasi peneliti berkenaan dengan signifikan butir-butir ataupun satuan data sejalan dengan pemahaman yang ingin diperoleh; 4) penilaian atas butir ataupun satuan data sehingga membuahkan kesimpulan; baik atau buruk, tepat atau tidak tepat, signifikan atau tidak signifikan.

Tabel 2. Deskripsi Data Dan Analisis Data

\begin{tabular}{|c|l|l|}
\hline Lokusi & \multicolumn{1}{|c|}{ Ilokusi } & \multicolumn{1}{|c|}{ Perlokusi } \\
\hline Tempat itu jauh & \multicolumn{1}{|c|}{ Tempat itu jauh } & \multicolumn{1}{c|}{ Tempat itu jauh } \\
\hline Mengandung pesan & $\begin{array}{l}\text { Metapesan 'Jangan pergi ke } \\
\text { sana!' }\end{array}$ & $\begin{array}{l}\text { Metapesan (Dalam pikiran mitratutur } \\
\text { ada keputusan) “Saya tidak akan pergi } \\
\text { ke sana.” }\end{array}$ \\
\hline Löna sökhi mbanua hö’ö & Löna sökhi mbanua hö’ö & Löna sökhi mbanua hö’ö \\
\hline Kampung itu rusuh & $\begin{array}{l}\text { Salah tingkah di kampung itu } \\
\text { langsung dibunuh }\end{array}$ & Di kampung itu sering pembunuhan \\
\hline
\end{tabular}

Berdasarkan hal di atas maka penulis dapat memodifikasi hasil penelitian sesuai denga pendapat Subanindyo (2012:52) mengatakan data yang telah dikumpulkan diolah, dianalisa secara kualitatif dan bersifat deskriptif. Selanjutnya data yang telah dikumpulkan akan diolah dengan langkah-langkah sebagai berikut: (a). Untuk data yang diperoleh sebagai temu bual, dilakukan simplikasi daripada bahan serta klarifikasi kumpulan sesuai dengan materi kajian, dan (b). Data kualitatif daripada sumber primer maupun sekunder diberikan penafsiran secara kualitatif. Penggunaan angka hanya sebatas angka persentase.

\section{HASIL DAN PEMBAHASAN}

Data-data yang diperoleh dan dibahas merupakan tindak tutur yang terdapat dalam kegiatan diskusi pada pembelajaran berbicara di SD Negeri NO. 078467 Buhawa Hilimbowo. Jenis tindak tutur yang ditemukan dalam kegiatan diskusi pada pembelajaran berbicara SD Negeri NO. 078467 Buhawa Hilimbowo meliputi tindak tutur lokusi, ilokusi dan perlokusi. Dilihat dari jenis lokusi terdapat bentuk berita, tanya dan perintah. Lokusi bentuk mendominasi dalam kegiatan diskusi di SD Negeri NO. 078467 Buhawa Hilimbowo, selanjutnya bentuk tanya dan perintah.

Dilihat dari tindak tutur ilokusi, ditemukan tindak ilokusi asertif, direktif, ekpresif, komisif dan deklaratif. Bentuk tindak tutur ilokusi asertif paling banyak muncul dalam penelitian ini, kemudian disusul direktif, ekpresif, deklaratif dan terakhir komisif. Dilihat dari tindak tutur perlokusi dalam penelitian ini, ditemukan perlokusi membuat mitra tutur melakukan sesuatu, terbujuk, tertarik, kesal, maklum, senang, dan mengurangi ketegangan.

Berdasarkan cara penyampaiannya, ditemukan jenis tindak tutur langsung dan tidak langsung. Tindak tutur langsung lebih mendominasi dalam penelitian ini. Berdasarkan makna kata-kata yang menyusun ditemukan tindak tutur literal dan tidak literal. Jenis tindak tutur literal lebih banyak muncul dibandingkan dengan tindak tutur tidak literal.

Dilihat dari interseksi tindak tutur langsung, tidak langsung, literal dan tidak literal dalam kegiatan diskusi pada pembelajaran berbicara di SD Negeri NO. 078467 Buhawa Hilimbowo, ditemukan tindak tutur langsung literal, langsung tidak literal, tindak tutur tidak langsung literal dan tindak tutur tidak langsung tidak literal. Interseksi tindak tutur langsung literal lebih 
mendominasi dibandingkan dengan interseksi tindak tutur yang lain dalam penelitian ini. Untuk lebih jelasnya, interseksi tindak tutur langsung, tidak langsung, literal, tidak literal dapat dilihat pada tabel 5 .

Berdasarkan penelitian yang dilakukan dalam kegiatan diskusi pada pembelajaran berbicara di SD Negeri NO. 078467 Buhawa Hilimbowo, ditemukan fungsi tindak tutur menginformasikan, bertanya, memerintah, menyatakan, menyebutkan, menunjukkan, mengakui, menuntut, mempertahankan, menyanggah, meminta, menyarankan, mengeluh, menyindir, mengucapkan maaf, mengucapkan terima kasih, mengucapkan salam, mengkritik, memuji, mengizinkan, melarang, menawarkan, membatalkan, melakukan sesuatu, mengurangi ketegangan, membuat senang, membuat terbujuk, membuat tertarik, membuat maklum, dan membuat kesal.

Dalam penelitian tindak tutur dalam diskusi pada pembelajaran berbicara di SD Negeri NO. 078467 Buhawa Hilimbowo berdasarkan tujuan tindak dari pandangan penutur ditemukan tindak tutur lokusi, ilokusi dan perlokusi. Berdasarkan bentuk penyampaiannya ditemukan tindak tutur langsung dan tidak langsung. Selain itu, berdasarkan pengungkapan makna ditemukan tindak tutur literal dan tidak literal. Tindak tutur tersebut dibagi dalam beberapa jenis dengan masing-masing fungsi. Berikut jenis tindak tutur dengan masing-masing fungsi dalam kegiatan diskusi pada pembelajaran berbicara di SD Negeri NO. 078467 Buhawa Hilimbowo.

Jenis dan fungsi tindak tutur dalam kegiatan diskusi pada pembelajaran berbicara di SD Negeri NO. 078467 Buhawa Hilimbowo akan dijabarkan pada bagian ini. Berikut penjabaran jenis dan tindak tutur tersebut.

a. Tindak Tutur Lokusi

Tindak tutur lokusi adalah tindak mengucapkan sesuatu yang tidak terkait dengan konteks. Jika melihat hasil penelitian dalam diskusi pada pembelajaran berbicara di SD Negeri NO. 078467 Buhawa Hilimbowo.

b. Tindak Tutur Ilokusi

Tindak tutur ilokusi adalah tindak tutur yang selain untuk menyatakan sesuatu juga untuk melakukan sesuatu dan tindak tutur ilokusi sangat bergantung pada konteks. Berdasarkan penelitian Tindak Tutur dalam Diskusi pada Pembelajaran Berbicara di SD Negeri NO. 078467 Buhawa Hilimbowo, ditemukan tindak ilokusi asertif, direktif, ekpresif, komisif dan deklaratif.

c. Tindak Tutur Perlokusi

Tindak tutur perlokusi adalah tuturan yang memiliki efek atau daya pengaruh yang ditimbulkan dari tuturan penutur terhadap mitra tutur. Berdasarkan penelitian yang dilakukan dalam diskusi pada pemebelajaran berbicara siswa di SD Negeri NO. 078467 Buhawa Hilimbowo.

\section{SIMPULAN}

Pada bagian ini dibahas mengenai kesimpulan hasil penelitian, implikasi, keterbatasan penelitian dan saran yang berkaitan dengan tindak tutur dalam kegiatan diskusi pada pembelajaran berbicara di SD Negeri NO. 078467 Buhawa Hilimbowo.

\section{A. Kesimpulan}

Berdasarkan hasil penelitian dan pembahasan yang telah dilakukan, maka dapat diambil kesimpulan sebagai berikut: 
1. Tindak tutur yang ditemukan dalam kegiatan diskusi pada pembelajaran berbicara di SD Negeri NO. 078467 Buhawa Hilimbowo dilihat dari tujuan tindak dari pandangan penutur adalah tindak tutur lokusi, tindak tutur ilokusi dan tindak tutur perlokusi.

2. Tindak tutur yang ditemukan dalam kegiatan diskusi pada pembelajaran berbicara di SD Negeri NO. 078467 Buhawa Hilimbowo dilihat dari cara penyampaian adalah tindak tutur langsung dan tindak tutur tidak langsung.

3. Tindak tutur yang ditemukan dalam kegiatan diskusi pada pembelajaran berbicara di SD Negeri NO. 078467 Buhawa Hilimbowo dilihat dari pengungkapan makna adalah tindak tutur literal dan tindak tutur tidak literal.

4. Fungsi tindak tutur yang ditemukan dalam kegiatan diskusi pada pembelajaran berbicara di SD Negeri NO. 078467 Buhawa Hilimbowo adalah fungsi menginformasikan, bertanya, memerintah, menyatakan, menyebutkan, menunjukkan, mengakui, menuntut, mempertahankan, menyanggah, meminta, menyarankan, mengeluh, menyindir, mengucapkan maaf, mengucapkan terima kasih, mengucapkan salam, mengkritik, memuji, mengizinkan, melarang, menawarkan, membatalkan, melakukan sesuatu, mengurangi ketegangan, membuat senang, membuat terbujuk, membuat tertarik, membuat maklum, dan membuat kesal.

B. Implikasi

Berdasarkan kesimpulan hasil penelitian dapat diajukan kemungkinan yang diharapkan dapat diimplikasikan sebagai berikut ini.

1. Dengan adanya penelitian ini, siswa di SD Negeri NO. 078467 Buhawa Hilimbowo dapat menggunakan tindak tutur sesuai dengan konteks yang melatari pembelajaran di sekolah khususnya pada diskusi kelas. Dengan demikian, tujuan pembelajaran akan tercapai yakni siswa dapat berkomunikasi dengan baik sesuai dengan konteks yang ada.

2. Dengan adanya penelitian ini, guru bahasa Indonesia mengetahui tentang bidang kajian pragmatik yang dapat dimasukkan dalam kurikulum pelajaran bahasa Indonesia pada keterampilan berbicara khususnya diskusi.

\section{DAFTAR PUSTAKA}

Azman, A., Ambiyar, Simatupang, W., Karudin, A., Dakhi, O. (2020). Link And Match Policy In Vocational Education To Address The Problem Of Unemployment. International Journal Of Multi Science, 1(6), 76-85.

Bertens, K. (2004) Etika. Gramedia Pustaka Utama, Jakarta.

Bawamenewi, A. (2019). Pengembangan Bahan Ajar Memprafrasekan Puisi "Aku” Berdasarkan Model Pembelajaran Problem Based Learning (PBL). Jurnal Review Pendidikan dan Pengajaran, 2(2), 310-323.

E. Kosasih. (2003) Kompetensi Ketatabahasaan dan Kesusastraan. Yrama Widya, Bandung.

Fajra, M., Jalinus, N., Jama, J., \& Dakhi, O. (2020). Model Pengembangan Kurikulum Sekolah Inklusi Berdasarkan Kebutuhan Perseorangan Anak Didik. Jurnal Pendidikan 21 (1), 51-63. https://doi.org/10.33830/jp.v21i1.746.2020

Fajra, M., Ambiyar, A., Rizal, F., \& Dakhi, O. (2020). Pengembangan Model Evaluasi Kualitas Output Pembelajaran Teknik Komputer dan Jaringan di SMK Kota Padang. Cakrawala: Jurnal Pendidikan, $14(1), \quad$ 1-9. https://doi.org/10.24905/cakrawala.v14i1.1480 
Ferdiansyah, Ambiyar, Zagoto, M. M., Putra, I E D., (2020). Pemanfaatan Media Pembelajaran berbasis E Learning dalam Meningkatkan Hasil Belajar pada Matakuliah Media Pembelajaran Musik. Komposisi: Jurnal Pendidikan Bahasa, Sastra, dan Seni, 21(1), 062-072. DOI: https://doi.org/10.24036/komposisi.v21i1.108082

Juanda, A; Rosdianto, K. (2006) Intisari Bahasa Indonesia Untuk SMA. Pustaka Setia, Bandung.

Kosasih (2003) Kompetensi Ketatabahasaan dan Kesusastraan. Yrama Widya, Bandung.

Maryaeni (2005) Metode Penelitian Kebudayaan. Bumi Aksara, Malang.

Maryani, Yani \& Mumu (2005) Intisari, Bahasa Dan Sastra Indonesia Untuk SMA. Pustaka Setia, "tanpa kota".

Masril, M., Dakhi, O., Nasution, T., Ambiyar. (2020). Analisis Gender Dan Intellectual Intelligence Terhadap Kreativitas. Edukasi: Jurnal Pendidikan, 18 (2), 182-191. https://doi.org/10.31571/edukasi.v18i2.1847

Masril, M., Jalinus, N., Jama, J., \& Dakhi, O. (2020). Implementasi Pembelajaran Berbasis Masalah Pada Kurikulum 2013 Di SMK Negeri 2 Padang. Konstruktivisme: Jurnal Pendidikan Dan Pembelajaran , 12 (1), 12-25.

Napitupulu, V. (1988) Filsafat Pendidikan. Bumi Agung, Medan.

Sarumaha, R., Harefa, D., \& Zagoto, M.M. (2018). Upaya Meningkatkan Kemampuan Pemahaman Konsep geometri Transformasi Refleksi Siswa Kelas XII-IPA-B SMA Kampus Telukdalam Melalui Model Pembelajaran Discovery learning Berbantuan Media Kertas Milimeter. Jurnal Education and development, 6 (1); 90-96. Institut Pendidikan Tapanuli Selatan.

Zagoto, Maria M., Nevi Yarni \& Dakhi, O (2019). Perbedaan Individu dari Gaya Belajarnya Serta Implikasinya Dalam Pembelajaran. Jurnal Review Pendidikan dan Pengajaran, 2(2), 259-265.

Zagoto, Maria M. \& Dakhi, O (2018). Pengembangan Perangkat Pembelajaran Matematika Peminatan Berbasis Pendekatan Saintifik Untuk Siswa Kelas XI Sekolah Menengah Atas. Jurnal Review Pendidikan dan Pengajaran, 1(1), 157-170.

Zagoto, Maria M. (2018). Pengembangan Perangkat Pembelajaran Matematika Berbasis Realistic Mathematic Educations Untuk Siswa Kelas V Sekolah Dasar, Jurnal Education And Development, vol. 3, no. 1, p. 53, Feb. 2018. 